Synthetic and fermentation products

Properly killed brewer's and fodder yeasts can be valuable supplements to rations adequately fortified with minerals (see Table I) (Temperton \& Dudley, 1940-I). Chlorella and bacterial preparations may also be produced commercially in the future.

Synthetic methionine will become important if offered at a price competing with the methionine and metabolizable calories contributed by normal concentrates-it is the amino-acid limiting the value of many practical rations.

\title{
REFERENCES
}

Almquist, H. J. (194I). F. Nutr. 21, 347.

Bender, A. E., Miller, D. S. \& Tunnah, E. J. (1953). Proc, Nutr. Soc, r2, ii.

Cama, H. R. \& Morton, R. A. (1950). Brit. F. Nutr. 4, 297.

Carpenter, K. J. (1951). Brit. $\mathscr{F}$. Nutr. 5, 243.

Carpenter, K. J., Duckworth, J. \& Ellinger, G. M. (r954). F. agric. Sci. (In the Press.)

Carpenter, K. J., Duckworth, J., Ellinger, G. M. \& Shrimpton, D. H. (1952). F. Sci. Fd Agric. 3, 278

Carpenter, K. J. \& Ellinger, G. M. (195I). Biochem. F. 48, liij.

Clandinin, D. R. (1949). Poult. Sci. 28, 128.

De Man, T. J. ( I949). Tijdschr. Diergeneesk. 74, 677.

Draper, C. I. \& Evans, R. J. (1944). Poult. Sci. 23, 189.

Duckworth, J. (1954). Proc. Nutr. Soc. 13, 3 I.

Evans, R. E. (1952a). F. agric. Sci. 42, 422.

Evans, R. E. (1952b). Ұ. agric. Sci. 42, 438 .

Hale, R. W. \& Bolton, W. (1948). F. agric. Sci. 38, 437.

Hegsted, D. M., Tsongas, A. G., Abbott, D. B. \& Stare, F. J. (r946). F. Lab. clin. Med. 3r, 26 r.

Heiman, V., Carver, J. S. \& Cook, J. W. (1939). Poult. Sci. 18, 464.

Hill, D. C. (1943-4). Sci. Agric. 24, 55I.

March, B., Biely, J. \& Young, R. J. (1950). Poult. Sci. 29, 444.

Pettit, J. H., Slinger, S. J., Evans, E. V. \& Marcellus, F. N. (r943-4). Sci. Agric. 24, 201.

Richardson, L. R. (1947). F. Nutr. 36, 45I.

Robertson, E. I., Carver, J. S. \& Cook, J. W. (1940). Bull. Wash. St. agric. Exp. Sta. no. 388.

Robinson, K. L. (1954). Proc. Nutr. Soc. 13, 27.

Serfontein, P. J. (1947). Bull. Dep. Agric. S. Afr. no. 280.

'Temperton, H. \& Dudley, F. J. (ı940-I). Harper Adams Util. Poult. F. 26, 172.

Underwood, E. J., Conochie, J., Reed, F. M. \& Smyth, R. (1950). Aust. vet. F. 26, 323.

Woodman, H. E. \& Evans, R. E. (1951). F. agric. Sci. 41, I02.

\section{The Use of Synthetic Vitamins and Antibiotics in Non-ruminant Feeding}

\author{
By K. L. RoBinson, Department of Agricultural Chemistry, \\ the Queen's University of Belfast
}

Throughout the war, and the years immediately after, the scarcity of feeding-stuffs was of more immediate practical importance to the farmer than the cost, since the latter was related to the prices paid for livestock products. Even though pig and poultry meals now sell at about $£ 37$ /ton, compared with $\oint_{1} 15$ in 1949 , the demand has expanded to a marked degree as a result of the retention of the principle of 
relating the price of the main product to the cost of the feeding-stuffs. Any contribution that the use of synthetic vitamins and antibiotics can make in reducing costs is, however, worthy of examination, especially in view of the calls on farmers for greater production coupled with increased efficiency.

\section{Vitamins in poultry diets}

Consideration is largely confined to vitamins $A$ and $D$, riboflavin and vitamin $B_{12}$ in relation to intensive conditions of management.

\section{Riboflavin}

In experiments at the Agricultural Research Institute (Northern Ireland), Prentice, Baskett $\&$ Robertson (I930) showed that chicks maintained semi-intensively could be fed on mineralized soya-cereal diets from hatching until commencement of laying without detriment to subsequent egg production. These investigations were continued for a number of years, during which occasional difficulty was encountered due to an obscure form of leg-weakness, controllable by skim milk or yeast (Prentice, I933a). As an insurance against this malaise, ultimately identified as riboflavin deficiency, it became the practice to buttress chick diets with expensive riboflavin-rich animal proteins, no other suitable forms of the vitamin being then available (Common \& Bolton, r942). It should be noted that chicks on the vegetable-protein régimes tended to grow rather more slowly during the first few weeks than those given animal proteins, but the difference in body-weight subsequently disappeared.

In relation to laying birds the extended series of trials carried out in Northern Ireland in ${ }^{1928-33}$ (Prentice, I933b) is of interest. Birds under semi-intensive conditions, with access to grass, and receiving a mash composed of cereals and a mineral supplement consistently produced around 200 eggs in their pullet year; no substantial benefit was derived from additions of soya-bean meal or fish meal. These results suggest the possibility of some reduction in the cost of current rations, under more intensive indoor conditions, if essential supplementary factors can be adequately provided.

More recently Carpenter \& Duckworth (195I) have shown that chicks under fully intensive conditions can be successfully reared on all-vegetable diets up to the onset of laying if a specific riboflavin supplement is provided. They concluded that an important contribution made by animal by-products was riboflavin, and that if this vitamin is included other deficiencies are of a mild and transitory nature.

\section{Vitamin $B_{12}$}

The place of vitamin $B_{12}$ in poultry feeding has received considerable attention. It has been generally found that breeding hens on normal diets can fortify their progeny with sufficient vitamin $B_{12}$ for early growth and development; equally it has been shown that maternal reserves can be readily depleted. Reviewing the position under American conditions, Cravens (1952) considers that no advantage 
may be expected from vitamin $B_{12}$ supplements to laying birds maintained intensively on litter, but that in general its addition to breeders' diets is desirable.

\section{Vitamins $A$ and $D$}

Until a year or two ago cod-liver oil was almost the only source of vitamin $D$ as a food supplement. Since this one is, on the whole, expensive and rather inconvenient, its use tended to restrict unduly the inclusion of vitamin $\mathrm{D}$ in poultry foods. Changes in husbandry such as from free-range to intensive indoor systems of egg production will probably increase the need for the vitamin and thus the more recently available dry vitamin $D_{3}$ concentrates are likely to be a valuable addition to the range of animal feeding-stuffs. Dry vitamin A concentrates may be less widely used because of their comparatively greater cost and the counter attraction of dried-grass meal.

\section{Vitamins in pig diets}

The prewar attempts to cheapen poultry feeding had their counterpart in pig feeding. During the years $1926-38$ it was shown in an extensive series of trials (Crowther, 1939) that no advantage was derived from animal proteins or cod-liver oil where weanling pigs had access to an open yard and regularly received small amounts of green food.

\section{Vitamins $A$ and $D$}

The provision of vitamins $\mathrm{A}$ and $\mathrm{D}$ in pig diets for intensive systems has long been a particular problem in the United Kingdom, since the addition of cod-liver oil has generally been discouraged by the bacon curers because of the adverse effects on body fat. Thus, as with poultry, the advent of inexpensive non-oily vitamin concentrates is noteworthy.

\section{Riboflavin}

The direct addition of riboflavin to weaner diets seems to have been widely adopted since the advent of inexpensive supplements. Although this lacks extensive experimental justification, it has come about partly because of the prevalence in young pigs of scouring, skin troubles and lack of appetite during the years of fishmeal shortage. At Belfast we have found considerable variations in the riboflavin contents of supposedly similar pig meals, and not infrequently the level was appreciably below the optimum.

\section{Vitamin $B_{12}$}

Although young pigs have been found to benefit from small amounts of raw liver or liver extract, there has been little published evidence of favourable responses to vitamin $B_{12}$ under United Kingdom conditions. Robinson, Coey \& Burnett (1952) found vitamin $B_{12}$ additions to an all-vegetable diet without effect on scouring and retarded growth of weanling pigs that had received all-vegetable 
creep food and whose dams had been given a similar diet during lactation, although a diet containing $10 \%$ fish meal (or an antibiotic) rapidly produced a beneficial response. Bell (1952) also obtained no response from vitamin $B_{12}$ in all-vegetable weaner diets but noted a beneficial effect upon the young pigs when the vitamin was given to the sows during gestation.

\section{Antibiotics in pig and poultry diets}

With commercial egg production, Cravens (1952) indicates occasional improvements in egg production after the addition of antibiotics to the food; it would appear probable, however, that with laying birds, as has often been found with younger birds and with fattening pigs, little response to antibiotics may be obtained under traditionally good feeding and management. Even with young growing animals it is questionable whether antibiotics can be usefully linked with highquality dietaries and extensive husbandry, and it is possible that their future may lie more in enabling cheaper and less attractive diets to be used, under intensive conditions, without detriment to production.

In a number of pig-feeding trials (Robinson et al. 1952, 1953) an allvegetable diet containing $20 \%$ earthnut-cake meal was compared with a diet containing $10 \%$ fish meal; in every instance the latter gave appreciably better liveweight gains associated with greater food intake and improved appetite. No doubt these effects may have been in part related to differences in nutritive value, but since the increased appetite, on ad lib. feeding, was observed from the outset it is difficult to resist the conclusion that palatability was also important and that the pigs grew better on fish-meal diets partly because they happened to like such food and would eat more of it. When antibiotics were added to the all-vegetable diets the pigs made live-weight gains similar to those of the untreated fish-meal groups, one obvious reason for this being that supplementation increased the appetite and so facilitated an increased food intake.

One of the biggest problems of intensive husbandry with young animals is the decline in appetite under the highly artificial indoor conditions. Hitherto this has been combated under U.K. conditions by keeping the fibre content low and adding as much animal protein as practicable, both of which help to minimize the unattractiveness of various all-vegetable mixtures; antibiotics would appear to offer a means of maintaining a high food intake on cheaper and relatively unpalatable diets. It is possible that this aspect of antibiotic feeding will prove more important than that of attempting to improve on the production already attainable with high-quality diets. Finally, it should be noted also that some recent work in the U.S.A. has been directed to a re-evaluation of the protein requirements of pigs when given antibiotics, and it would appear that some reduction in conventional protein levels may be possible (Sheffy, 1952).

\section{Conclusions}

The review of prewar experiments indicates that high levels of production were obtained with pigs and poultry on cheap all-vegetable diets, provided they had 
access to the open air and received some green food; it would appear that these conditions were necessary, at least in part, to supply factors such as vitamins $A$ and $D$, riboflavin and vitamin $B_{12}$, which are now available as inexpensive dry concentrates. Although American experience with suitably vitaminized soya-maize diets suggests that these are capable of giving good production under intensive conditions, it is questionable whether the supplemented all-vegetable diets at present practicable in the U.K. would be sufficiently attractive to secure the necessary degree of food intake under the intensive systems now prevalent. There seem to be reasonable grounds for the suggestion that antibiotics could help to overcome this defect in palatability.

\section{REFERENCES}

Bell, J. M. (1952). Sci. Agric. 32, 135.

Carpenter, K. J. \& Duckworth, J. (195I). F. agric. Sci. 4I, 297.

Common, R. H. \& Bolton, W. (1942). F. Soc. Chem. Ind., Lond., 61, 153.

Cravens, W. W. (1952). Proceedings of the 1952 Cornell Nutrition Conference for Feed Manufacturers. Ithaca, N.Y.: Cornell University.

Crowther, C. (1939). Rep. Harper-Adams Coll. Pig Feed Sta. no. 2.

Prentice, J. H. (1933a). Rep. agric. Res. Inst. N. Ire. I932-33, p. 23.

Prentice, J. H. (1933b). F. Minist. Agric. N. Ire. 4, 116.

Prentice, J. H., Baskett, R. G. \& Robertson, G. S. (1930). World's Poult. Congr. Iv. London, sect. B, no. 37, p. 224 .

Robinson, K. L., Coey, W. E. \& Burnett, G. S. (1952). F. Sci. Fd Agric. 3, 448.

Robinson, K. L., Coey, W. E. \& Burnett, G. S. (1953). Emp. F. exp. Agric. (In the Press.)

Sheffy, B. E. (1952). Proceedings of the 1952 Cornell Nutrition Conference for Feed Manufacturers. Ithaca, N.Y.: Cornell University.

\section{Economies in Pig and Poultry Feeding}

\section{By J. DuckworTH, Rowett Research Institute, Bucksburn, Aberdeenshire}

In the narrowest sense economy in feeding consists of devising the cheapest rations that still provide the minimum amounts of nutrients needed for particular rates of growth and production.

In a broader sense the feed supplies in a country as a whole and, in an importing country such as this, the world's feed supplies must be considered to see whether economical rations advocated could be used on a wide scale, in terms of the demands they would create for individual feeding-stuffs.

In the widest sense economy in feeding embraces production problems other than those of feed supplies and costs, since an economical feeding system may impose production charges that reduce profit and thus bar acceptance by the farmer. For example, restricted feeding of pigs, although increasing the efficiency of feed conversion, can extend rearing time to the extent that extra labour costs and smaller throughput reduce profits. Similarly, it may pay better on occasion to provide a richer ration for birds housed intensively in order to reduce labour charges and land use, than to use a more economical ration for the same flock widely dispersed on grass range. 